\title{
Effects of Organic Cations on the Gram-negative Cell Wall and Their Bactericidal Activity with Ethylenediamine- tetra-acetate and Surface Active Agents
}

\author{
By J. G. VOSS \\ Research Division, Miami Valley Laboratories, \\ The Proctor \& Gamble Company, Cincinnati, Ohio 45239, U.S.A.
}

(Accepted for publication 20 March $\mathbf{1 9 6 7 )}$

\begin{abstract}
SUMMARY
When Gram-negative cell walls were damaged by lysozyme and ethylenediaminetetra-acetic acid (EDTA) in tris buffer, tris played an active role through its action as an organic cation. Other organic cations such as aliphatic amines and quaternary ammonium compounds were more effective than tris in modifying the cell wall and making it permeable to other solutes. The most effective organic cations had one $C_{12}$ to $C_{16}$ alkyl chain. At pHro, EDTA IO0 $\mu \mathrm{g}$. $/ \mathrm{ml}$ and $N, N$-dimethyldodecylamine (DDA) $2.5 \mu \mathrm{g} . / \mathrm{ml}$. modified the cell wall of Escherichia coli so as to permit a more than $99.99 \%$ kill by $20 \mu \mathrm{g} . / \mathrm{ml}$. of a zwitterionic surface active agent, 2-hydroxy-3(dimethylhexadecylammonio) propane-I-sulphonate (HAPS), in 10 min. at $37^{\circ}$. At these concentrations, the individual compounds were bactericidally ineffective. Four other Gram-negative species were shown to be similarly susceptible to killing by this system. Together, EDTA and DDA appeared to remove surface components of the Gram-negative cell wall. Alone, DDA and other organic cations removed somatic antigens from the cell wall.
\end{abstract}

\section{INTRODUCTION}

Gram-negative bacteria are generally susceptible to the bactericidal action of cationic surface active agents, but are usually unaffected by those anionic and zwitterionic agents which are active against Gram-positive organisms. It was suggested by Voss (1963) that the greater resistance of Gram-negative species may be due to the greater complexity of their cell walls, which exclude the agent from the interior of the cell.

The Gram-negative cell wall may be so modified by treatment with EDTA in tris buffer at $\mathrm{pH} 8$ as to permit conversion of the cell by lysozyme to osmotically fragile rods (Voss, 1964) or 'osmoplasts' (Asbell \& Eagon, 1966a). In studies on Escherichia coli modified by treatment with EDTA and tris buffer, it was observed that such organisms may be killed by treatment with zwitterionic agents to which the organisms are normally resistant. As in the case of lysis by lysozyme, killing by the agent indicates changes induced in the cell wall by EDTA and tris buffer. Further study revealed that tris is not a physiologically inert buffer, but plays a specific role as an organic cation in modifying the permeability of the cell wall; other organic cations are much more effective than tris. Elucidation of the role of the organic cation forms the substance of this report. 


\section{METHODS}

Organisms. The test organisms were Escherichia coli (ATCC 10536), E. freundii, Pseudomonas aeruginosa, Proteus mirabilis, and Salmonella typhi; S. typhi TY $2 \mathrm{~V}$ and O9OI and E. freundii (BALLERUP I07) were obtained through the courtesy of the late Dr P. R. Edwards (Communicable Disease Center, Public Health Service, Atlanta, Ga.), S. typhi $9992 \mathrm{~V}$ and 12839 were obtained from the American Type Culture Collection. Escherichia coli was obtained as ATCC 10536 and used in the earlier part of this work; after the observation that this culture produced acid but no gas from glucose or lactose, it was replaced with a fresh, gas-forming culture of ATCC 10536 from the American Type Culture Collection with no discernible difference in results.

Test compounds. EDTA was used as the disodium salt; solutions were adjusted to $\mathrm{pH} 8 \cdot 0$ before sterilization. The zwitterionic agent 2-hydroxy-3-(dimethylhexadecylammonio)-propane-I-sulphonate (HAPS), was prepared and purified in our laboratories, and sterilized as a $0.1 \%$ solution in $0.85 \% \mathrm{NaCl}$; it is much less soluble in water alone. $N, N$-dimethyldodecylamine (DDA) was prepared by distillation of 'dimethyl coconut amine' (Armour). Some amines were derived from coconut or soybean oil, and thus contain a mixture of alkyl chains. Other compounds which were not available commercially were synthesized in our laboratories. Fatty amines were dissolved in ethanol, and diluted with water before use; at values up to about $\mathrm{pH} \mathrm{ro}$, they are present principally as cations.

Bactericidal tests. All organisms except Proteus mirabilis were grown in brain heart infusion broth (Difco) for $24 \mathrm{hr}$ at $37^{\circ}$. Plate counts were made on brain heart infusion agar incubated at $37^{\circ}$ for $24 \mathrm{hr} ; P$. mirabilis was grown in nutrient broth, and plated on nutrient agar overlaid with plain agar to inhibit spreading. Exposure to bactericidal agents was done as described earlier (Voss, 1963) for $10 \mathrm{~min}$. at $37^{\circ}$ with suspensions of about 60-120 million washed organisms $/ \mathrm{ml}$.

Lysis. Changes in optical density of suspensions of organisms at room temperature were measured with a Coleman Junior spectrophotometer at $660 \mathrm{~m} \mu$.

Precipitin tests. Escherichia coli was harvested from ten $150 \mathrm{~mm}$. plates, washed, and suspended in $400 \mathrm{ml}$. water. These suspensions contained 3-4 mg. dry wt. organisms $/ \mathrm{ml}$. Portions were treated for Io min. at $37^{\circ}$ with DDA Io and $50 \mu \mathrm{g} . / \mathrm{ml}$. or with EDTA, HAPS, dodecyltrimethylammonium bromide (DTAB), or alkyldimethylbenzylammonium chloride (Roccal), all $50 \mu \mathrm{g} . / \mathrm{ml}$. in the presence or absence of $\mathrm{Na}_{2} \mathrm{CO}_{3} 100 \mu \mathrm{g}$. $/ \mathrm{ml}$. Organisms were removed by centrifugation for $20 \mathrm{~min}$. at $5000 \mathrm{~g}$. The supernatant fluids were tested for antigenic activity in double diffusion tests in agar, using as the source of antibody a $1 / 5$ dilution of rabbit antiserum prepared against whole $E$. coli organisms.

\section{RESULTS}

\section{Activity of cations other than tris}

Tris was more effective than other buffers (e.g. phosphate buffer) in promoting the bactericidal activity of a mixture of EDTA and HAPS. The corresponding nitro compound, tris(hydroxymethyl) nitromethane, was inactive, indicating that it is the free amino group of tris buffer which affects the cell wall. Table I shows the results of a comparison of other amines and related compounds for activity in promoting the bactericidal action of EDTA and HAPS against Escherichia coli at concentrations at 
Table I. Survival of Escherichia coli in systems containing EDTA $(100 \mu \mathrm{g} . / \mathrm{ml})+.H A P S(20 \mu \mathrm{g} . / \mathrm{ml})+$ amines or other compounds

Test compound

Tris(2-Amino-2-hydroxymethyl-

propane-1,3-diol)

Tris(hydroxymethyl)nitromethane

Ammonia

Methylamine

Ethylamine

Diethanolamine

3-Aminopropanol

n-Propylamine

n-Butylamine

sec-Butylamine

Dibutylamine

n-Hexylamine

n-Octylamine

$n$-Decylamine

$n$-Dodecylamine

$n$-Hexadecylamine

$N$-Methyldodecylamine

$N, N$-Dimethyldodecylamine (DDA)

$N, N$-Dimethylhexadecylamine

Didecylamine

Dicoco amine $\dagger$

$N$-Methyl dicoco amine $\dagger$

$N$-Methyl disoya amine $\ddagger$

Coco-I,3-propylene diamine $\uparrow$

Dodecyl piperidine

$N, N$-Dimethyldodecylamine oxide

Coco ethanolamine $f$

Coco amide $\dagger$
Conen.

$\left(\times 10^{-4} \mathrm{M}\right)$

500

250

500

500

500

500

250

250

125

500

250

I 25

500

250

125

250

125

250

I 25

125

$62 \cdot 5$

125

$62 \cdot 5$

$31 \cdot 2$

$7 \cdot 8$

$3 \cdot 9$

I $5 \cdot 6$

0.244

0. 122

0.244

0.122

$0 \cdot 244$

o. 244

O. I 22

0.061

0.244

O. I 22

0.244

0.244

o. I 22

0.244

$0 \cdot 244$

$0 \cdot 244$

O. I 22

0.244

o. 122

O. 244

0.244

$0 \cdot 244$
Survival $(\%)$

$\overbrace{\text { In }}^{\text {With test }}$

complete systems compound alone

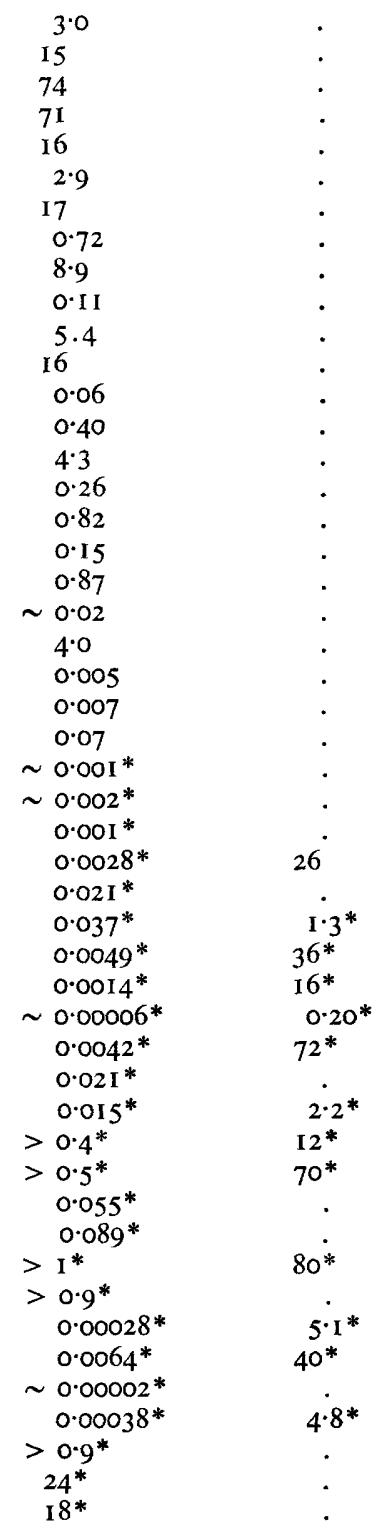

* In the presence of $100 \mu \mathrm{g} . / \mathrm{ml}$. sodium triphosphate.

$\dagger$ Derived from coconut oil fatty acids consisting of about $65 \%$ lauric acid, $25 \%$ myristic acid, and $10 \%$ palmitic acid.

$\ddagger$ Derived from soybean oil fatty acids consisting of about $12 \%$ palmitic acid $25 \%$ oleic acid, and $53 \%$ linoleic acid. 
which the latter two compounds together were ineffective. A number of amines of low molecular weight, more or less closely related to tris, were found to possess similar activity. As the length of the alkyl chain increased, the bactericidal activity of the mixture increased markedly. Concentrations of the amine buffers were decreased as activity increased; therefore sodium triphosphate $\left(\mathrm{Na}_{5} \mathrm{P}_{3} \mathrm{O}_{10}\right)$ I00 $\mu \mathrm{g} . / \mathrm{ml}$. was added to maintain at $\mathrm{pH} 8 \cdot 5-9 \cdot 0$. Maximum activity was reached with amines containing alkyl chains of $12-\mathrm{I} 6 \mathrm{C}$ atoms. The further substitution on the $\mathrm{N}$ atom of one or two methyl groups had little effect. Amines with two alkyl chains were less active. Such

Table 2. Per cent survival of Escherichia coli in systems containing EDTA $(100 \mu \mathrm{g} . / \mathrm{ml}$. $)+$ $\mathrm{Na}_{2} \mathrm{CO}_{3}(100 \mu \mathrm{g} . / \mathrm{ml}$.) $+\mathrm{HAPS}(20 \mu \mathrm{g} . / \mathrm{ml}$.$) , and organic cations or related compounds$

\begin{tabular}{|c|c|c|c|}
\hline \multirow[b]{2}{*}{ Test compound } & \multirow[b]{2}{*}{$\begin{array}{l}\text { Concentra- } \\
\text { tion } \\
(\mu \mathrm{g} . / \mathrm{ml} .)\end{array}$} & \multicolumn{2}{|c|}{ Survival $(\%)$} \\
\hline & & $\begin{array}{l}\text { Complete } \\
\text { system }\end{array}$ & $\begin{array}{l}\text { Test compound } \\
+\mathrm{Na}_{2} \mathrm{CO}_{3} \\
\text { only }\end{array}$ \\
\hline yldodecylamine (DDA) & $2 \cdot 5$ & 0.0074 & I5 \\
\hline sulphoxide & 5 & $>6$ & \\
\hline hethyl sulphoxide & 5 & $>6$ & . \\
\hline hyl sulphone & 5 & $>6$ & . \\
\hline thyl sulphide & 5 & $>6$ & \\
\hline ethylsulphoxonium methosulphate & $2 \cdot 5$ & $0.008 \mathrm{I}$ & 38 \\
\hline thylsulphonium iodide & $2 \cdot 5$ & 0.0033 & 68 \\
\hline ridine & $2 \cdot 5$ & $>6$ & \\
\hline lethylammonium bromide & $2 \cdot 5$ & 0.018 & 32 \\
\hline ylammonium bromide & $2 \cdot 5$ & 0.067 & 88 \\
\hline ium chloride & $2 \cdot 5$ & 0.019 & 78 \\
\hline ylbenzylammonium chloride & $2 \cdot 5$ & 0.19 & 0.10 \\
\hline $\begin{array}{l}\text { 3-bis-(trimethylammonio)- } \\
\text { bromide } \\
\text { decyl-3-(trimethylammonio)- }\end{array}$ & $2 \cdot 5$ & 0.00074 & 43 \\
\hline ium dibromide & $2 \cdot 5$ & 0.00095 & 59 \\
\hline ino-imidazolidine & 2 & 0.135 & 30 \\
\hline ylamino)-dodecane & $2 \cdot 5$ & 0.0017 & 70 \\
\hline hyldodecylamine & $2 \cdot 5$ & O.II & 54 \\
\hline
\end{tabular}

related compounds as coconut alkyl ethanolamine or the amides of coconut fatty acids were ineffective, while other compounds such as coco-I,3-propylene diamine and dodecyl piperidine were highly active. The increasing activity of the aliphatic amines with EDTA and HAPS was not due to the increasing bactericidal activity of the amines alone as the length of the alkyl chain grew; the active amines effectively killed $E$. coli, in the presence of EDTA and HAPS, at concentrations at which the amines alone possessed only slight bactericidal activity.

A further series of organic cations and related compounds, including DDA, is compared in Table 2. In this case, the compounds were tested in the presence of EDTA I00 $\mu \mathrm{g}$. $/ \mathrm{ml}$., HAPS, $20 \mu \mathrm{g}$. $/ \mathrm{ml}$. and $\mathrm{Na}_{2} \mathrm{CO}_{3}$ Io० $\mu \mathrm{g}$. $/ \mathrm{ml}$. to buffer the system at $\mathrm{pH}$ Io. $\mathrm{Na}_{2} \mathrm{CO}_{3}$ was used instead of sodium triphosphate as a buffer to avoid combining the chelating effects of EDTA and triphosphate. Four non-ionic alkyl sulphur compounds were ineffective in increasing bactericidal activity, but two cationic sulphonium and sulphoxonium compounds were highly effective, as were a number of quaternary ammonium compounds and additional amines. It is evident that there was no specific requirement for a positively charged $\mathrm{N}$ atom. A compound with an alkyl chain of $\mathrm{C}_{12}$ 
or longer and a positively charged group at one end was sufficient to give high bactericidal activity in the presence of EDTA, HAPS and an alkaline buffer.

\section{Action of the bactericidal system}

For further work, DDA was chosen as the organic cation; at a concentration of $2.5 \mu \mathrm{g} . / \mathrm{ml}$., it showed only very limited bactericidal activity against Escherichia coli at $\mathrm{pH}$ Iо. EDTA was used at $100 \mu \mathrm{g}$. $/ \mathrm{ml}$., at which concentration it was present in excess; decrease to $10 \mu \mathrm{g} . / \mathrm{ml}$. caused no significant loss of activity. At $20 \mu \mathrm{g}$. $/ \mathrm{ml}$. and above, HAPS alone was not appreciably bactericidal for $E$. coli; however, increasing the concentration in the presence of the other components of the system increased killing, and decreasing the concentration decreased the killing. The concentration of $\mathrm{Na}_{2} \mathrm{CO}_{3}$ was not critical. A number of alkaline buffers gave similar results in the range $\mathrm{pH}$ 9-ro.

EDTA could be replaced by a number of other chelating agents; however, only $N$-hydroxyethylethylenediaminetriacetic acid (Versenol), diethylenetriaminepentaacetic acid (Versenex 80), and I,2-diaminocyclohexane- $N, N^{\prime}$-tetra-acetic acid were as effective as EDTA.

Table 3. Effect of omission of single components of the bactericidal system on kill of Escherichia coli

EDTA
$(\mu \mathrm{g} . / \mathrm{ml}$.
100
100
0
100
100

$\begin{gathered}\text { DDA } \\ (\mu \mathrm{g} . / \mathrm{ml} .)\end{gathered}$
2.5
0
2.5
2.5
2.5

$\mathrm{Na}_{2} \mathrm{CO}_{3}$
$(\mu \mathrm{g} . / \mathrm{ml}$.
100
100
100
0
100

HAPS
$(\mu \mathrm{g} . / \mathrm{ml}$.
20
20
20
20
0

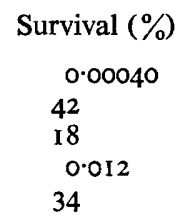

HAPS, which is regarded as the actual lethal agent in the bactericidal system through its presumed effect on the cytoplasmic membrane (see Hotchkiss, I946; Salton, I95I), could be replaced by other zwitterionic agents such as betaines, or by cationic quaternary ammonium compounds. Many of the latter are themselves highly bactericidal, and perhaps fulfil the function of organic cation and surface active agent simultaneously. Anionic and non-ionic surface active agents were ineffective as replacements for HAPS.

The fact that each component of the bactericidal system containing EDTA, DDA, HAPS and $\mathrm{Na}_{2} \mathrm{CO}_{3}$ was required for full activity is indicated by the data in Table 3 . Omission of EDTA, DDA, or HAPS caused a sharp decrease in the killing of Escherichia coli; lack of $\mathrm{Na}_{2} \mathrm{CO}_{3}$ caused a much smaller decrease.

The bactericidal action of the components of the EDTA + DDA $+\mathrm{Na}_{2} \mathrm{CO}_{3}+\mathrm{HAPS}$ system against Escherichia coli was studied in greater detail by exposing the organisms to one or two components under the conditions of the bactericidal test, removing the organisms by centrifugation, and then exposing them to the remainder of the system. The results of this study (Table 4) implied that EDTA and DDA acted jointly to exert a non-lethal effect on the cell wall, which thus became more permeable to HAPS. The surface active agent penetrates the wall and causes death of the organism, presumably by damaging the cytoplasmic membrane. The role of $\mathrm{Na}_{2} \mathrm{CO}_{3}$ was relatively non-specific, though it appeared to increase the effect of DDA more than that of EDTA or HAPS. Although killing might be influenced by carry-over of test compounds 
from the initial to the final exposure, it seems clear that the initial effect of EDTA and especially of DDA was required before HAPS could kill the organism. This conclusion is supported by the survival curve shown in Fig. I. It is assumed that the low rate of killing for the first minute or two represented the time required for EDTA and DDA to affect the cell wall.

Table 4. Role of the components of the bactericidal system in killing Escherichia coli

Concentrations of reagents: EDTA (100 $\mu \mathrm{g} . / \mathrm{ml}$.), DDA $\left(2.5 \mu \mathrm{g} . / \mathrm{ml}\right.$.), $\mathrm{Na}_{2} \mathrm{CO}_{3}(100 \mu \mathrm{g} . / \mathrm{ml}$.), HAPS (20 $\mu \mathrm{g} . / \mathrm{ml}$.).

Initial and final exposures: 10 min. at $37^{\circ} \mathrm{C}$.

Initial exposure to

EDTA

DDA

EDTA + DDA

$\mathrm{EDTA}+\mathrm{DDA}+\mathrm{Na}_{2} \mathrm{CO}_{3}$

$\mathrm{EDTA}+\mathrm{Na}_{2} \mathrm{CO}_{3}$

$\mathrm{DDA}+\mathrm{Na}_{2} \mathrm{CO}_{3}$

HAPS

$\mathrm{HAPS}+\mathrm{Na}_{2} \mathrm{CO}_{3}$

EDTA + HAPS

DDA + HAPS

$\mathrm{EDTA}+\mathrm{Na}_{2} \mathrm{CO}_{3}+\mathrm{HAPS}$

$\mathrm{DDA}+\mathrm{Na}_{2} \mathrm{CO}_{3}+\mathrm{HAPS}$
Final exposure to

$$
\mathrm{DDA}+\mathrm{Na}_{2} \dot{\mathrm{CO}}{ }_{3}+\mathrm{HAPS}
$$

$\mathrm{EDTA}+\mathrm{Na}_{2} \mathrm{CO}_{3}+\mathrm{HAPS}$

$\mathrm{Na}_{2} \mathrm{CO}_{3}+\mathrm{HAPS}$

HAPS

DDA + HAPS

EDTA + HAPS

$\mathrm{EDTA}+\mathrm{DDA}+\mathrm{Na}_{2} \mathrm{CO}_{3}$

$\mathrm{EDTA}+\mathrm{DDA}$

$\mathrm{DDA}+\mathrm{Na}_{2} \dot{\mathrm{CO}}_{3}$

$\mathrm{EDTA}+\mathrm{Na}_{2} \mathrm{CO}_{3}$

DDA

EDTA
Final pH

value Survival (\%)

. $\quad$ II 4

$9 \cdot 9 \quad 49$

. 80

$9.9 \quad 0.49$

. 118

$9.9 \quad 0.015$

. 34

$8 \cdot 0 \quad 0.0013$

$\begin{array}{cr}\cdot .6 & 79\end{array}$

$7.6<0.015$

. $\quad 87$

$\begin{array}{ll}9 \cdot 9 & 2 \cdot 8\end{array}$

60

$7 \cdot 4 \quad 75$

. 84

$10 \cdot 0-1 \cdot 8$

- 92

$9 \cdot 9 \quad 45$

27

$7 \cdot 9 \quad 9 \cdot 2$

$6 \cdot 8 \quad \mathrm{I} 6$

$6 \cdot 8 \quad 12$

Six consecutive exposures of 12 isolates of Escherichia coli to the action of the $\mathrm{EDTA}+\mathrm{DDA}+\mathrm{Na}_{2} \mathrm{CO}_{3}+\mathrm{HAPS}$ system did not produce any evidence that the survivors had mutated to a state of greater resistance to the bactericidal action.

Because of the great superiority of other alkyl cations over tris buffer in promoting the bactericidal activity of HAPS in the presence of EDTA, the efficiency of DDA in inducing lysis of Escherichia coli by lysozyme was compared with that of tris buffer. As shown in Table 5, 0.2I mg. DDA was more effective than $2.4 \mathrm{mg}$. tris, and about as effective as $12 \mathrm{mg}$. tris, in promoting lysis as measured by the decrease in optical density at $660 \mathrm{~m} \mu$.

A basic assumption throughout this work was that the surface active substance was the actual lethal agent, and that its action on the cytoplasmic membrane would be accompanied by a leakage of $\mathbf{N}$ and $\mathbf{P}$ from the cell. To test this, organisms at twice 
the usual concentration were exposed to the EDTA+DDA $+\mathrm{Na}_{2} \mathrm{CO}_{3}+\mathrm{HAPS}$ system for Io min. at $37^{\circ}$. The $\mathrm{N}$ and $\mathrm{P}$ content of the supernatant fluid after centrifugation was compared with that of a control suspension of organisms. It was found that 4-5 $\mu \mathrm{g} . \mathrm{N} / \mathrm{ml}$. and $0.8 \mu \mathrm{g} . \mathrm{P} / \mathrm{ml}$. were released on killing the organisms. Ultraviolet absorption curves showed a peak at $260 \mathrm{~m} \mu$ in the supernatant fluid of killed organisms, with an optical density of $0 \cdot 2-0 \cdot 3$. Calculations based on adenine ribonucleotide as a model system indicated that this quantity of nucleic acid would yield about $0.4-0.6 \mu \mathrm{g} . \mathrm{P} / \mathrm{ml}$. A major proportion of the $\mathbf{P}$ released may be accounted for as nucleic acid, as would

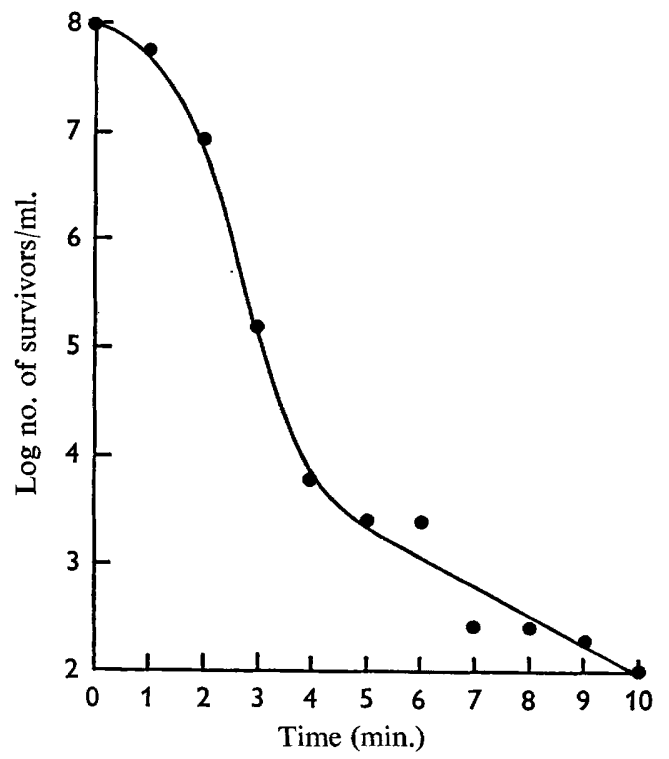

Fig. I. Survival of Escherichia coli on exposure at $37^{\circ}$ to EDTA ( $100 \mu \mathrm{g} . / \mathrm{ml}$.) + DDA $(2 \cdot 5 \mu \mathrm{g} . / \mathrm{ml})+.\mathrm{Na}_{2} \mathrm{CO}_{3}(100 \mu \mathrm{g} . / \mathrm{ml}$. $)+$ HAPS $(20 \mu \mathrm{g} . / \mathrm{ml}$.$) .$

Table 5. Lysis of Escherichia coli by lysozyme, EDTA, and DDA or tris buffer*

\begin{tabular}{|c|c|c|c|c|c|c|c|}
\hline \multirow[b]{2}{*}{$\begin{array}{c}\text { EDTA } \\
\text { (mg.) }\end{array}$} & \multirow[b]{2}{*}{$\begin{array}{l}\text { DDA } \\
\text { (mg.) }\end{array}$} & \multirow[b]{2}{*}{$\begin{array}{l}\text { tris } \\
\text { (mg.) }\end{array}$} & \multirow[b]{2}{*}{$\underset{\text { (mg.) }}{\mathrm{Na}_{2} \mathrm{CO}_{3}}$} & \multicolumn{4}{|c|}{$\begin{array}{l}\text { Decrease in } \\
\text { special density }\end{array}$} \\
\hline & & & & $\begin{array}{l}\text { lysozyme } \\
\text { (mg.) }\end{array}$ & $\begin{array}{c}\mathrm{pH} \\
\text { value }\end{array}$ & $\begin{array}{l}(660 \mathrm{~m} \mu) \\
\text { at } 30 \mathrm{~min} .\end{array}$ & $\begin{array}{l}\text { Viscosity } t \text { at } \\
30 \mathrm{~min} \text {. }\end{array}$ \\
\hline $1 \cdot 0$ & 0.21 & . & 0.2 & 0.1 & $7 \cdot 8$ & 0.21 & ++ \\
\hline $1 \cdot 0$ & 0.021 & & 0.2 & $O \cdot I$ & $7 \cdot 6$ & 0.08 & - \\
\hline$I \cdot 0$ & • & 48 & . & $0 \cdot 1$ & $8 \cdot I$ & 0.30 & $++t$ \\
\hline$I \cdot O$ & . & I 2 & . & $0 \cdot \mathbf{I}$ & $8 \cdot I$ & 0.20 & $++t+$ \\
\hline$I \cdot O$ & . & $2 \cdot 4$ & . & 0.1 & $7 \cdot 5$ & 0.04 & - \\
\hline$I \cdot O$ & 0.21 & . & 0.2 & . & $8 \cdot 0$ & 0.12 & - \\
\hline $1 \cdot 0$ & . & 48 & . & . & $8 \cdot I$ & $0 . I I$ & ++ \\
\hline
\end{tabular}

be expected from the increased viscosity which appeared on lysis of the suspensions. This viscosity was decreased rapidly by adding a trace of deoxyribonuclease.

That the bactericidal activity of the EDTA + DDA $+\mathrm{Na}_{2} \mathrm{CO}_{3}+$ HAPS system was not restricted to Escherichia coli is shown by the data in Table 6. Four other Gram- 
negative species were also killed by this system. At the concentrations used, none of the individual components were actively bactericidal. It is of interest that possession of an outermost layer of Vi antigen by some strains of Salmonella typhi and by the V dissociant of $E$. freundii appeared to confer some slight resistance to the killing effect.

Table 6. Bactericidal activity of a mixture of EDTA $(100 \mu \mathrm{g} . / \mathrm{ml})+.D D A(2.5 \mu \mathrm{g} . / \mathrm{ml})+$ $\mathrm{Na}_{2} \mathrm{CO}_{3}(100 \mu \mathrm{g} . / \mathrm{ml})+.\mathrm{HAPS}(20 \mu \mathrm{g} . / \mathrm{ml}$.) against organisms other than Escherichia coli, and the effect of $V i$ antigen on survival

\begin{tabular}{lcc}
\multicolumn{1}{c}{ Test organism } & Vi antigen & $\%$ Survival \\
Proteus mirabilis & & 0.17 \\
Pseudomonas aeruginosa & - & 0.0048 \\
Escherichia freundii (BALLERUP I07 W) & - & 0.0045 \\
E. freundii (BALLERUP I07V) & + & 0.034 \\
Salmonella typhi O90I & - & $0.005^{*}$ \\
S. typhi TY 2V & + & $0.013^{*}$ \\
S. typhi $9992, \mathrm{~V}$ & + & $0.0082^{*}$ \\
S. typhi I 2839 & + & $0.14^{*}$
\end{tabular}

* With DDA (I $\mu \mathrm{g} . / \mathrm{ml}$.), at which concentration DDA alone was not actively bactericidal against S. typhi.

\section{Removal of somatic antigens by organic cations}

It seemed probable that EDTA and DDA removed some surface components of the cell wall, thus rendering it more permeable to HAPS. To test this, washed suspensions of Escherichia coli were treated for Io min. at $37^{\circ}$ with dodecyltrimethylammonium bromide (DTAB), alkyldimethylbenzylammonium chloride (Roccal), DDA, EDTA or HAPS (at Io or $50 \mu \mathrm{g} . / \mathrm{ml}$.), in the presence or absence of $\mathrm{Na}_{2} \mathrm{CO}_{3} 100 \mu \mathrm{g} . / \mathrm{ml}$. The content of somatic antigens in these extracts was compared by the double diffusion method in agar, using rabbit antisera prepared against whole organisms. Comparison of the zones of precipitation showed that antigens were removed by DDA $50 \mu \mathrm{g} . / \mathrm{ml}$. and even more effectively by the other two cationic agents, DTAB and Roccal. Extraction by DDA ro $\mu \mathrm{g} . / \mathrm{ml}$. was less effective, but still evident. Evidence of reaction consisted primarily of a broad, diffuse zone of precipitate; in some cases minor bands of precipitate also indicated the presence of two slower-moving antigenic components. $\mathrm{Na}_{2} \mathrm{CO}_{3}$ had no perceptible effect on the extraction of antigens by the cations; $\mathrm{Na}_{2} \mathrm{CO}_{3}$, EDTA and HAPS were essentially ineffective in removing antigens from the cell wall.

\section{DISCUSSION}

Although Weidel, Frank \& Martin (1960) concluded that the outermost layer of the cell wall of Escherichia coli is lipoprotein, the somatic antigens which are responsible for specific agglutination of Gram-negative bacteria are known to be polysaccharide or lipopolysaccharide. Shands (I965), by using ferritin-labelled antibody, demonstrated extension of somatic antigen for some distance beyond the cell wall of $E$. coli and Salmonella typhimurium. It is probably an over-simplification to regard the outermost layer of the multilayered cell envelope as consisting solely of lipoprotein or lipopolysaccharide. From biochemical and immunological evidence, both appear to be present.

Martin (1963) suggested that the complex wall of Gram-negative organisms affords more protection to the organism than does the simpler Gram-positive wall. Loss or decrease of somatic antigens at the cell surface decreases the resistance of Gram- 
negative organisms to normal serum or to EDTA and lysozyme (Herzberg \& Green, I964; Osawa \& Muschel, I964; Wardlaw, I963). Similarly, results given here indicate that absence of Vi antigen on Escherichia freundii and Salmonella typhi organisms is associated with greater susceptibility of the organisms. Thus, the demonstrated removal of somatic antigens from $E$. coli by DDA and other organic cations would be expected to increase the susceptibility of the organisms to deleterious agents.

Work with several species has shown that EDTA causes loss of lipid, lipoprotein or lipopolysaccharide from the cell wall (Colobert, 1958; Gray \& Wilkinson, 1965; Leive, 1965). Repaske (1958) indicated that EDTA removed inorganic cations from cell walls. The importance of calcium and other divalent cations in the cell walls of various Gram-negative species (Humphrey \& Vincent, I962; Asbell \& Eagon, I966 $a, b$ ) appears to be due to its function as a salt bridge in binding macromolecules on the surface of the cell wall.

Removal of surface components of the Gram-negative cell wall by organic cations and EDTA, or disorganization of the structure of the wall, may make it susceptible to the action of lysozyme and permeable to other solutes. When these solutes are surface active compounds which can now penetrate the cell wall, they may cause death of the cell by damaging the cytoplasmic membrane (Hotchkiss, I946; Salton, I95I; Gilby \& Few, 1960). In the system studied here, the lethal effect of HAPS on Escherichia coli is an indicator of changes induced by EDTA and DDA in the cell wall in the same manner as lysis by lysozyme indicates damage by EDTA and tris buffer (Repaske, 1958).

There is a growing realization that tris buffer actively modifies the effect of EDTA on the cell wall. Goldschmidt \& Wyss (1966) showed that tris and other amines might assist the rupture of Azotobacter cysts by EDTA, but attributed the activity of the amines to the formation of complexes with EDTA. Asbell \& Eagon (1966 $a, b)$ observed that tris buffer enhanced the lethal effect of EDTA on Pseudomonas aeruginosa. However, many workers have used EDTA in tris buffer without recognizing that the latter specifically affects the cell wall. For example, Nossal \& Heppel (I966) exposed Escherichia coli to sucrose +EDTA in tris buffer preparatory to osmotic shock for the release of degradative enzymes, and Wolin (1966) lysed Vibrio succinogenes with EDTA in tris buffer. The work reported here suggests that a number of organic cations, including tris, specifically affect the Gram-negative cell wall by removing surface components.

It may be speculated that chelating agents and organic cations act together to cause non-lethal damage to the walls of Gram-negative organisms by breaking salt bridges and by salt formation with anionic polymers (lipoproteins, lipopolysaccharides) at the cell surface. Removal of these constituents of the cell wall renders the wall more permeable to other compounds, which can then penetrate to the interior of the cell. The penetration by a zwitterionic agent, such as HAPS, results in disorganization of the cytoplasmic membrane and death of the organism. The modified cell wall is still impermeable to some other compounds, such as anionic surfactants.

Organic cations containing an alkyl chain with about I2-I6 C atoms may be used at low concentrations as a tool for dissection of the Gram-negative cell wall and for the preparation of partially purified extracts of somatic antigens. The $\mathrm{O}$ and $\mathrm{Vi}$ antigens of Salmonella typhi have been extracted by treatment of heavy suspensions of organisms with low concentrations of DDA (unpublished). With this organism, EDTA too is 
effective in removing somatic antigens under similar conditions. Perhaps antigens suitable for use as vaccines could be prepared from a number of Gram-negative species in this fashion.

The capable assistance of Rebecca Sosebee and R. Bush is gratefully acknowledged, as are numerous constructive discussions with $\mathrm{Dr} \mathbf{H}$. H. Reller.

\section{REFERENCES}

AsbelL, M. A. \& EAGon, R. G. (1966a). The role of multivalent cations in the organization and structure of bacterial cell walls. Biochem. biophys. Res. Commun. 22, 664.

AsBell, M. A. \& EAGON, R. G. (I966b). Role of multivalent cations in the organization, structure, and assembly of the cell wall of Pseudomonas aeruginosa. J. Bact. 92, 380.

Colobert, L. (1958). Étude de la lyse de Salmonelles pathogènes provoquée par le lysozyme, après délipidation partielle de la paroi externe. Annls Inst. Pasteur, Paris 95, I56.

GilBy, A. R. \& FEW, A. V. (1960). Lysis of protoplasts of Micrococcus lysodeikticus by ionic detergents. J. gen. Microbiol. 23, 19.

GoldschmidT, M. C. \& WYSS, O. (I966). Chelation effects on Azotobacter cells and cysts. J. Bact. 9I, 120.

Gray, G. W. \& Wilkinson, S. G. (1965). The effect of ethylenediaminetetraacetic acid on the cell walls of some Gram-negative bacteria. J. gen. Microbiol. 39, 385 .

Herzberg, M. \& Green, J. H. (I964). Composition and characteristics of cell walls of smooth strains of Salmonella typhimurium and derived rough variants. J. gen. Microbiol. 35, $42 \mathrm{I}$.

Hoтchkiss, R. D. (1946). The nature of the bactericidal action of surface active agents. Ann. N.Y. Acad. Sci. 46, 479.

Humphrey, B. \& VinCENT, J. M. (1962). Calcium in cell walls of Rhizobium trifolii. J. gen. Microbiol. 29, 557.

LeIVE, L. (1965). Release of lipopolysaccharide by EDTA treatment of Escherichia coli. Biochem. biophys. Res. Commun. 21, 290.

Martin, H. H. (1963). Bacterial protoplasts-a review. J. theoret. Biol. 5, I.

Nossal, N. G. \& Heppel, L. A. (1966). The release of enzymes by osmotic shock from Escherichia coli in exponential phase. J. biol. Chem. 24I, 3055.

Osawa, E. \& Muschel, L. H. (1964). Studies relating to the serum resistance of certain Gramnegative bacteria. $J$. exp. Med. II9, $4 \mathrm{I}$.

REPASKe, R. (1958). Lysis of Gram-negative organisms and the role of Versene. Biochim. biophys. Acta 30, 225.

SALTON, M. R. J. (I95I). The adsorption of cetyltrimethylammonium bromide by bacteria, its action in releasing cellular constituents and its bactericidal effects. J. gen. Microbiol. 5, 39I.

SHANDS, J. W. (1965). Localization of somatic antigen on Gram-negative bacteria by electron microscopy. J. Bact. 9o, 266.

Voss, J. G. (1963). Effect of inorganic cations on bactericidal activity of anionic surfactants. J. Bact. 86, 207.

Voss, J. G. (1964). Lysozyme lysis of Gram-negative bacteria without production of spheroplasts. J. gen. Microbiol. 35, 313 .

WARDLAW, A. C. (1963). The complement-dependent bacteriolytic action of normal human serum. II. Cell wall composition of sensitive and resistant strains. Can. J. Microbiol. 9, 4I.

Weidel, W., Frank, H., \& Martin, H. H. (1960). The rigid layer of the cell wall of Escherichia coli strain B. J. gen. Microbiol. 22, 158.

Wolin, M. J. (1966). Lysis of Vibrio succinogenes by ethylenediaminetetraacetic acid or lysozyme. J. Bact. $9 \mathbf{I}, \mathbf{1} 78 \mathbf{I}$. 